\title{
Hybridization Between the Deoxyribonucleic Acids of Some Strains of Heterofermentative Lactic Acid Bacteria
}

\author{
ELLEN I. GARVIE
}

National Institute for Research in Dairying, Shinfield, Reading RG2 9AT, England

\begin{abstract}
The degree of hybridization between the deoxyribonucleic acids (DNAs) of some different species of heterofermentative lactic acid bacteria was estimated. The DNAs from each of 25 strains comprising 12 species were hybridized with labeled DNAs from the type or reference strains of five species. The results suggest a very close relationship between Leuconostoc mesenteroides, Leuconostoc dextranicum, and Leuconostoc cremoris, whereas Leuconostoc oenos was found to be unrelated to other species of the genus. The results also indicate that Lactobacillus confusus and Lactobacillus viridescens are more allied to the leuconostocs than to other lactobacilli.
\end{abstract}

At one time the leuconostocs were classified as streptococci because of their morphology (1, 11), but for the past several decades leuconostocs and streptococci have been separated into two genera in the family Streptococcaceae (12). However, as knowledge of the leuconostocs has increased, it has become apparent that they share several properties with the heterofermentative lactobacilli and have many differences from the streptococci.

At present there are six named species of Leuconostoc which are generally accepted (see Table 1). Leuconostoc oenos alone is acidophilic and is distinct from the other five species (8). These five species have many common properties which are also found in Lactobacillus confusus and Lactobacillus viridescens $(9,23)$. The other species of heterofermentative lactobacilli appear to have fewer properties in common with Lactobacillus confusus and Lactobacillus viridescens than these last-named species have with the leuconostocs (9). Deoxyribonucleic acid (DNA) hybridization studies have been made in an attempt to clarify the relationships of these bacteria. The results of these studies are reported here.

\section{MATERIALS AND METHODS}

Bacterial strains. The strains used in this study are listed in Table 1. They were all obtained from the National Collection of Dairy Organisms ( $\mathrm{NCDO}$ ). Several had been included in earlier work (6-10). Bacteria were prepared for use as previously described (10). The strains of Lactobacillus brevis and Lactobacillus buchneri were grown in MRSB (18) at $30 \mathrm{C}$, and the strains of Lactobacillus fermentum were grown at $37 \mathrm{C}$.

Purification of DNA. Cells were grown for extraction of DNA in medium 1 (a yeast-glucose-peptone broth, $\mathrm{pH}$ 6.5); cells of Leuconostoc oenos were grown in a modified medium 1 at $\mathrm{pH} 4.8$ (8). Cells were harvested in the late logarithmic or early stationary phase of growth and were washed twice in water. Escherichia coli cells were grown on nutrient agar overnight at $37 \mathrm{C}$. The cells were washed off the agar with water and then given a second wash in water.

The wet, packed cells were frozen at $-20 \mathrm{C}$ and were stored at this temperature at least overnight and often for several days. The frozen cells were prepared for use by covering them with a small amount of water and allowing them to thaw at room temperature. Cells of lactic acid bacteria were lysed overnight at $37 \mathrm{C}$ with lysozyme and Pronase in $3 \%$ 4-amino salicylate which was dissolved in standard saline citrate (SSC: $0.15 \mathrm{M}$ sodium chloride, $0.015 \mathrm{M}$ sodium citrate). The components of the lysing solution are shown in Table 2. These were added in the order shown in the table. Cells of Escherichia coli were not treated with lysozyme and Pronase but were suspended in 3\% 4-amino salicylate in SSC.

The lysed cells and the Escherichia coli cells were treated at $60 \mathrm{C}$ for $10 \mathrm{~min}$ with $0.5 \%$ isopropyl naphthalene sulfonate (15) by adding $2 \mathrm{ml}$ of a $6.25 \%$ solution to each $25 \mathrm{ml}$ of lysate or cell suspension.

The viscous solutions were deproteinized by shaking for $15 \mathrm{~min}$ in the cold with phenol water (10) saturated with SSC. A volume of chloroform-isoamyl alcohol (24:1) equal to a quarter of the aqueous volume was added to help separate the layers on centrifuging (3). After centrifuging, the viscous aqueous upper layer containing DNA was removed and deproteinized by shaking for $15 \mathrm{~min}$ with chloroform-isoamyl alcohol (24:1). The layers in this mixture were separated by centrifugation, and the DNA in the aqueous upper layer was precipitated with $66 \%$ ethanol and collected on a spooling rod.

Additional purification followed the method of Young and Spizizen (24). The spooled DNA was dispersed in SSC and treated with ribonuclease (final concentration, $50 \mu \mathrm{g} / \mathrm{ml}$ of DNA solution) for 30 min at $37 \mathrm{C}$, and then with Pronase (final concentration, $1.0 \mathrm{mg} / \mathrm{ml}$ of DNA solution) for $60 \mathrm{~min}$ at $37 \mathrm{C}$. The solution was deproteinized with $0.2 \%$ sodium deoxycholate in $2 \mathrm{M} \mathrm{NaCl}$. After $60 \mathrm{~min}$ of incubation at $37 \mathrm{C}$, the solutions were held overnight at 4 
TABLE 1. Bacterial strains used

\begin{tabular}{lrl}
\hline \multicolumn{1}{c}{ Species } & $\begin{array}{r}\text { NCDO } \\
\text { no. }\end{array}$ & $\begin{array}{c}\text { Additional informa- } \\
\text { tion }\end{array}$ \\
\hline Leuconostoc oenos & 1674 & Type strain \\
Leuconostoc mesenter- & 1707 & \\
oides & 523 & Reference strain \\
& 797 & B523 NCIB 9317 \\
Leuconostoc dextranicum & 768 & Strain 39 \\
& 529 & Reference strain \\
& 812 & NCDO 516 \\
Leuconostoc cremoris & 1589 & Does not form dextran \\
& 1590 & Does not form dextran \\
Leuconostoc lactis & 543 & Reference strain \\
& 828 & \\
Leuconostoc paramesen- & 546 & \\
teroides & 533 & Type strain \\
Lactobacillus viridescens & 8037 & \\
& 871 & Type strain \\
Lactobacillus confusus & 1655 & S41A \\
& 1586 & ATCC 10881; type \\
& & strain \\
Lactobacillus bermiforme & 1965 & \\
Lactobacillus fermentum & 1749 & Type strain \\
\hline & 110 & Neotype strain \\
& 1980 & Neotype strain \\
& 1975 & Lactobacillus coprophi- \\
& & K-12; NCTC 10538 \\
\hline
\end{tabular}

C. The DNA was separated from impurities by centrifugation and was precipitated with $66 \%$ ethanol. This procedure was repeated but with the Pronase treatment omitted. Finally, the DNA was twice precipitated with isopropyl alcohol (19). DNA was washed in ethanol and was finally dissolved in $0.1 \times$ SSC (SSC diluted 1:9 with water).

After each precipitation, at least $24 \mathrm{~h}$ were allowed for the subsequent solubilization of the DNA. This process was helped by occasionally warming the DNA in a water bath at 45 to $50 \mathrm{C}$, a temperature well below that at which thermal denaturation starts. As far as possible, sterile glassware and solutions were used during preparation to minimize the risk of bacterial growth during the long solubilization stages. This method of isolating DNA is discussed later.

Testing for purity. DNA solutions were tested for protein by the sensitive method of Lowry et al. (17), for ribonucleic acid (RNA) by the orcinol test for pentose (22), and for DNA concentration by the diphenylamine test of Burton (2). In addition, melting curves were plotted and hyperchromicity was calculated.

Labeled DNA. A $100-\mu \mathrm{Ci}$ amount of [methyl${ }^{3} \mathrm{H}$ ]thymidine (Amersham Radiobiochemicals) was added to each 1,000 ml of medium. Cells were grown and harvested. The DNA was isolated as described.

Hybridization of DNA. The method used was based on the membrane-filter method of Denhardt (5). Filters were loaded with heat-denatured, unlabeled DNA as described by De Ley and Tutgat (4) using 25-mm-diameter membrane filters (Millipore Corp.). The difference in optical density $(260 \mathrm{~nm})$ of the DNA solution before and after filtration together with that of the rinse was used to calculate the DNA on each filter. The calculation assumed that $10 \mu \mathrm{g}$ of heated DNA per ml gave an optical density at $260 \mathrm{~nm}\left(\mathrm{OD}_{260}\right)$ of 0.280 .

The filters were washed with $10 \mathrm{ml}$ of $6 \times \mathrm{SSC}$ and allowed to dry in air for 2 to $3 \mathrm{~h}$. They were then heated overnight at $60 \mathrm{C}$ in a vacuum desiccator over $\mathrm{P}_{2} \mathrm{O}_{5}$. The dried filters were stored at $4 \mathrm{C}$ in the vacuum desiccator.

The DNA-loaded filters were cut into quarters and marked with a pencil for identification. Three separate quarters were placed in each $5.0-\mathrm{ml}$ conical flask containing $1.4 \mathrm{ml}$ of $2 \times \mathrm{SSC}-30 \%$ dimethyl sulfoxide ( $\left.\mathrm{Me}_{2} \mathrm{SO}\right)$ (4). At least one of these quarters contained DNA homologous with the labeled DNA to be added. One flask in every batch contained a filter quarter saturated with $6 \times \mathrm{SSC}$ but without any DNA.

Labeled DNA was diluted in $0.1 \times$ SSC. It was sheared by passing 10 times through a hypodermic syringe $(25 \mathrm{G} \times 5 / 8)$ and denatured by holding at the temperature of boiling water for $10 \mathrm{~min}$ and then plunging into ice-cooled water. The solutions were then stored frozen at $-10 \mathrm{C}$. For use, they were diluted in $0.1 \times \mathrm{SSC}$, and $0.1 \mathrm{ml}$ was added to each flask containing the filter quarters. The concentration of DNA was adjusted so that the disintegrations per minute of the filter quarter containing homologous DNA were between 1,000 and 2,000.

After the labeled DNA was added, the flasks were manually shaken to $\mathrm{mix}$ the solutions and then shaken overnight in a water bath at $45 \mathrm{C}$.

The filter quarters were transferred to scintillation vials and washed three times in $5.0 \mathrm{ml}$ of $2 \times$

TABLE 2. Suspension used for lysing heterofermentative lactic acid bacteria

\begin{tabular}{|c|c|c|c|c|}
\hline Substance & Concentration & Solute & Pretreatment & $\begin{array}{l}\text { Amount in lys- } \\
\text { ing solution }\end{array}$ \\
\hline Wet-packed cells & & & & $1.0 \mathrm{~g}$ \\
\hline Water & & & & $4.5 \mathrm{ml}$ \\
\hline Pronase & $40 \mathrm{mg} / \mathrm{ml}$ & $\begin{array}{c}\text { EDTA-NaCl } \\
(\mathrm{pH} 7.0)^{b}\end{array}$ & Incubate $1 \mathrm{~h}, 37 \mathrm{C}$ & $0.25 \mathrm{ml}$ \\
\hline Lysozyme & $2.5 \mathrm{mg} / \mathrm{ml}$ & Water & & $2.0 \mathrm{ml}$ \\
\hline Concentrated saline citrate ${ }^{c}$ & & & & $0.75 \mathrm{ml}$ \\
\hline 4-Amino salicylate & $12 \%$ & SSC & & $2.5 \mathrm{ml}$ \\
\hline
\end{tabular}

"Total volume (excluding cells), $10.0 \mathrm{ml}$.

${ }^{b}$ EDTA, $0.1 \mathrm{M}$; $\mathrm{NaCl}, 0.15 \mathrm{M}$.

Concentrated saline citrate is SSC concentrated 10-fold. 
$\mathrm{SSC} ; 10.0 \mathrm{ml}$ of polyphosphor [methoxyethanol, 600 $\mathrm{ml}$; anisole, $400 \mathrm{ml}$; 2,5-diphenyloxazole, $7 \mathrm{~g}$; 1,4-bis(5-phenyloxazolyl)benzene, $6.3 \mathrm{~g}$; naphthalene, 100 g] was then added to the vials. The coating from the filter dissolved, leaving the transparent center part, which was then broken on a Whirlimix (Fisons Scientific Apparatus). Counts were made on a Phillips liquid scintillation counter (LSA 4500/01).

The reasons for using direct hybridization of DNA are given in the Discussion.

\section{RESULTS}

Purity of DNA. The protein concentration (wt/wt DNA) was less than $10 \%$ and, in most cases, it was less than 5\%. RNA proved more difficult to remove than protein, and it was necessary to precipitate twice with isopropyl alcohol to lower the concentration of RNA to between 5 and $10 \%$.

The hyperchromicity of DNA with a moles percent guanine plus cytosine $(\mathrm{mol} \% \mathrm{G}+\mathrm{C})$ of 38 to 50 is anticipated to be 0.42 to 0.39 . The DNA used in the hybridization experiments had a hyperchromicity of 0.37 to 0.39 . This was slightly lower than expected and was probably due to the protein, RNA, and other impurities absorbing at $260 \mathrm{~nm}$.

Testing the hybridization method. De Ley and Tutgat (4) have shown that $2 \times$ SSC plus $30 \% \mathrm{Me}_{2} \mathrm{SO}$ is a satisfactory solution for DNA/ DNA hybridization experiments using membrane filters. Preliminary trials comparing this solution with the preincubation mix of Denhardt (5) and with the formamide used by Kourilsky et al. (16) showed that the first solution was slightly more efficient than the others in preventing DNA from washing off the filters and in preventing labeled DNA from adhering to blank filters. Kourilsky et al. (16) demonstrated that several filters could be tested in a single container. Preliminary experiments not only confirmed these observations but also showed that the variation between two filters in the same flask was no greater than that between two filters in separate flasks. This technique has the advantages of economizing on the amount of labeled DNA used and of allowing a direct comparison of the DNA from different bacteria.

Loading of filters. The loaded filters were calculated to bear between 30 and $40 \mu \mathrm{g}$ of DNA $/ \mathrm{cm}^{2}$. De Ley and Tutgat (4) give a figure of $32 \mu \mathrm{g}$ of $\mathrm{DNA} / \mathrm{cm}^{2}$ for a saturated PHWP filter.

Labeled DNA. Preparations of labeled DNA were tested for contaminating protein and RNA. The counts per microgram were also estimated and were between 3,000 and 8,000 dpm for the leuconostocs. Lactobacillus confusus was more efficient than the leuconostocs at incorporating thymidine and had a count of about $20,000 \mathrm{dpm} / \mu \mathrm{g}$.

Relationships between lactic acid bacteria. Table 3 shows the degree of DNA/DNA hybridization between the various strains examined. Initially, labeled DNA was prepared from four strains, which were selected for the following reasons. The reference strains of Leuconostoc mesenteroides and the type strain of Lactobacillus confusus were chosen because these species cause difficulty in classification. Lactobacillus viridescens was used because the $\mathrm{G}+\mathrm{C}$ content of its DNA is intermediate between that of Lactobacillus confusus and that of Leuconostoc mesenteroides (10). In this instance, the type strain (NCDO 1655) of Lactobacillus viridescens was not used because it usually gives a low yield of DNA and is troublesome to handle. Lactobacillus viridescens NCDO 403, one of the original Niven strains, was chosen because it was known to give a higher yield of DNA and generally to behave better in preparation than the type strain. The second Leuconostoc species selected was Leuconostoc lactis, which has DNA with a higher $\mathrm{G}+\mathrm{C}$ content than other species of Leuconostoc (10). Here again the type strain of Leuconostoc lactis, NCDO 533, was not used, but NCDO 546 was selected because it is an easier strain with which to work.

After it was found that Leuconostoc paramesenteroides DNA failed to hybridize with Leuconostoc mesenteroides DNA, labeled DNA was prepared from Leuconostoc paramesenteroides NCDO 803, the type strain. Experiments could then be made reversing the labeled and unlabeled DNA, and the relationship of these two species could then be determined.

Hybridization of non-dextran-forming strains of leuconostocs. Two strains, NCDO 1589 and NCDO 1590, were included. They do not form dextran from sucrose but had been considered to belong to Leuconostoc dextranicum because phenotypically they differed from strains of the non-dextran-forming species Leuconostoc paramesenteroides (Table 4). The identity of NCDO 1589 and 1590 was supported by the results of DNA/DNA hybridization (Table 3).

\section{DISCUSSION}

Many methods have been described for the preparation of bacterial DNA and, of these, the one described in detail by Marmur (19) is most often used. However, for the heterofermentative lactic acid bacteria, this method gave a low yield of DNA, and the product contained pro- 
TABLE 3. Percent hybridization between the deoxyribonucleic acids of some heterofermentative lactic acid bacteria

\begin{tabular}{|c|c|c|c|c|c|c|c|c|c|c|c|}
\hline \multirow{3}{*}{ Bacteria } & \multirow{3}{*}{$\begin{array}{l}\text { NCDO } \\
\text { no. }\end{array}$} & \multicolumn{10}{|c|}{ Hybridization (\%) of labeled DNA from: } \\
\hline & & \multicolumn{2}{|c|}{$\begin{array}{l}\text { Leuconostoc mes- } \\
\text { enteroides } 523\end{array}$} & \multicolumn{2}{|c|}{$\begin{array}{l}\text { Leuconostoc lac- } \\
\quad \text { tis } 546\end{array}$} & \multicolumn{2}{|c|}{$\begin{array}{l}\text { Leuconostoc } \\
\text { paramesenter- } \\
\text { oides } 803\end{array}$} & \multicolumn{2}{|c|}{$\begin{array}{c}\text { Lactobacillus viri- } \\
\text { descens } 403\end{array}$} & \multicolumn{2}{|c|}{$\begin{array}{l}\text { Lactobacillus } \\
\text { confusus } 1586\end{array}$} \\
\hline & & Mean $^{a}$ & $\pm \mathrm{SEM}^{b}$ & Mean & $\pm \mathrm{SEM}$ & Mean & $\pm \mathrm{SEM}$ & Mean & $\pm \mathrm{SEM}$ & Mean & $\pm \mathrm{SEM}$ \\
\hline Leuconostoc oenos & $\begin{array}{l}1674 \\
1707\end{array}$ & $\begin{array}{l}15 \\
14\end{array}$ & $\begin{array}{l}7.1 \\
4.8\end{array}$ & $\begin{array}{r}11 \\
2\end{array}$ & $\begin{array}{l}6.6 \\
2.2\end{array}$ & & & $\begin{array}{l}0.5 \\
1\end{array}$ & $\begin{array}{l}3.3 \\
1.2\end{array}$ & $\begin{array}{r}4 \\
-5\end{array}$ & $\begin{array}{l}3.7 \\
4.1\end{array}$ \\
\hline $\begin{array}{l}\text { Leuconostoc mesenter- } \\
\quad \text { oides }\end{array}$ & $\begin{array}{l}523^{c} \\
768 \\
797\end{array}$ & $\begin{array}{r}100 \\
48 \\
80\end{array}$ & $\begin{array}{l}3.8 \\
4.2\end{array}$ & $\begin{array}{l}36 \\
38 \\
32\end{array}$ & $\begin{array}{l}6.8 \\
3.6 \\
6.5\end{array}$ & $\begin{array}{r}9 \\
10 \\
12\end{array}$ & $\begin{array}{l}3.4 \\
9.6 \\
6.7\end{array}$ & $\begin{array}{l}13 \\
14 \\
26\end{array}$ & $\begin{array}{l}3.7 \\
2.3 \\
1.7\end{array}$ & $\begin{array}{l}13 \\
15 \\
17\end{array}$ & $\begin{array}{l}1.5 \\
1.9 \\
0.4\end{array}$ \\
\hline $\begin{array}{l}\text { Leuconostoc dextrani- } \\
\quad \text { cum }\end{array}$ & $\begin{array}{r}529 \\
812 \\
1589 \\
1590\end{array}$ & $\begin{array}{r}110 \\
84 \\
104 \\
48\end{array}$ & $\begin{array}{r}9.3 \\
19.9 \\
3.6 \\
6.4\end{array}$ & $\begin{array}{l}22 \\
25 \\
30 \\
32\end{array}$ & $\begin{array}{l}9.0 \\
1.5 \\
5.7 \\
5.0\end{array}$ & $\begin{array}{l}15 \\
20\end{array}$ & $\begin{array}{l}4.9 \\
0.3\end{array}$ & $\begin{array}{l}20 \\
12 \\
26 \\
34\end{array}$ & $\begin{array}{l}7.7 \\
0.7 \\
1.5 \\
0.02\end{array}$ & $\begin{array}{l}16 \\
10 \\
17 \\
18\end{array}$ & $\begin{array}{l}3.1 \\
1.5 \\
0.1 \\
2.6\end{array}$ \\
\hline Leuconostoc cremoris & $\begin{array}{l}543 \\
828\end{array}$ & $\begin{array}{r}66 \\
105\end{array}$ & $\begin{array}{l}10.3 \\
17.1\end{array}$ & $\begin{array}{l}29 \\
35\end{array}$ & $\begin{array}{l}6.0 \\
5.7\end{array}$ & & & $\begin{array}{l}12 \\
21\end{array}$ & $\begin{array}{l}2.3 \\
6.0\end{array}$ & $\begin{array}{l}13 \\
13\end{array}$ & $\begin{array}{l}2.3 \\
0.5\end{array}$ \\
\hline Leuconostoc lactis & $\begin{array}{r}546^{*} \\
533 \\
2037\end{array}$ & $\begin{array}{l}49 \\
58 \\
39\end{array}$ & $\begin{array}{l}3.3 \\
1.4 \\
7.6\end{array}$ & $\begin{array}{r}100 \\
85 \\
90\end{array}$ & $\begin{array}{r}4.0 \\
27.4\end{array}$ & $\begin{array}{l}46 \\
37\end{array}$ & $\begin{array}{r}10.3 \\
9.5\end{array}$ & $\begin{array}{l}26 \\
20 \\
49\end{array}$ & $\begin{array}{l}5.9 \\
9.5 \\
0.2\end{array}$ & $\begin{array}{l}18 \\
18 \\
31\end{array}$ & $\begin{array}{r}2.3 \\
2.4 \\
14.1\end{array}$ \\
\hline $\begin{array}{l}\text { Leuconostoc parame- } \\
\text { senteroides }\end{array}$ & $\begin{array}{l}803^{r} \\
871\end{array}$ & $\begin{array}{r}6 \\
19\end{array}$ & $\begin{array}{l}1.8 \\
6.8\end{array}$ & $\begin{array}{l}13 \\
14\end{array}$ & $\begin{array}{l}1.2 \\
2.4\end{array}$ & $\begin{array}{r}100 \\
87\end{array}$ & 8.1 & $\begin{array}{l}19 \\
13\end{array}$ & $\begin{array}{l}2.0 \\
2.8\end{array}$ & $\begin{array}{l}28 \\
26\end{array}$ & $\begin{array}{l}3.3 \\
2.8\end{array}$ \\
\hline $\begin{array}{l}\text { Lactobacillus viri- } \\
\text { descens }\end{array}$ & $\begin{array}{r}403^{c} \\
1655\end{array}$ & $\begin{array}{l}23 \\
12\end{array}$ & $\begin{array}{l}3.2 \\
1.7\end{array}$ & $\begin{array}{l}21 \\
18\end{array}$ & $\begin{array}{l}3.3 \\
1.6\end{array}$ & 35 & 10.0 & $\begin{array}{r}100 \\
90\end{array}$ & 2.4 & $\begin{array}{l}50 \\
32\end{array}$ & $\begin{array}{l}8.8 \\
2.7\end{array}$ \\
\hline $\begin{array}{l}\text { Lactobacillus confu- } \\
\quad \text { sus }\end{array}$ & $1586^{r}$ & 15 & 2.1 & 15 & 1.5 & 46 & 5.8 & 39 & 9.3 & 100 & \\
\hline & $\begin{array}{r}930 \\
1975\end{array}$ & $\begin{array}{l}20 \\
14\end{array}$ & $\begin{array}{l}6.1 \\
3.8\end{array}$ & $\begin{array}{l}12 \\
20\end{array}$ & $\begin{array}{l}4.3 \\
1.4\end{array}$ & & & $\begin{array}{l}29 \\
64\end{array}$ & $\begin{array}{l}5.7 \\
2.5\end{array}$ & $\begin{array}{l}82 \\
86\end{array}$ & $\begin{array}{r}5.4 \\
10.7\end{array}$ \\
\hline $\begin{array}{l}\text { Lactobacillus vermi- } \\
\text { forme }\end{array}$ & 1965 & 22 & 4.5 & 17 & 4.0 & & & 9 & 1.9 & 10 & 2.3 \\
\hline Lactobacillus brevis & 1749 & -2 & 6.0 & -7 & 2.2 & & & 10 & 3.8 & 8 & 0.9 \\
\hline $\begin{array}{l}\text { Lactobacillus buch- } \\
\quad \text { neri }\end{array}$ & 110 & -5 & 11.1 & 3 & 4.0 & 10 & & 6 & 9.0 & 11 & 6.4 \\
\hline $\begin{array}{l}\text { Lactobacillus fermen- } \\
\text { tum }\end{array}$ & 1750 & 1 & 5.5 & 7 & 5.8 & & & 2 & 2.1 & 5 & 3.0 \\
\hline Escherichia coli & 1984 & 4 & 2.1 & 2 & 0.01 & & & 2 & 1.0 & -4 & 8.2 \\
\hline
\end{tabular}

" Mean of duplicate tests on several different days.

${ }^{b}$ SEM, Standard error of the mean.

" Strains from which labeled DNA was prepared.

tein and RNA in concentrations which were unacceptable for DNA/DNA hybridization studies. De Ley and Tutgat (4) found it necessary to modify the Marmur technique. A number of published procedures were tried, and the composite method described here was found to be the most satisfactory. Difficulties with the Marmur technique were encountered from the start, for the gram-positive lactic acid bacteria may not lyse with lysozyme when the cells are suspended in ethylenediaminetetraacetic acid (EDTA) saline at $\mathrm{pH}$ 8.0. The cells were ren- dered sensitive to lysozyme by first freezing and thawing them and then allowing lysozyme in dilute aqueous solution to come into contact with the cells which were suspended in water (20). Salt (see Table 1) was then added, and the $\mathrm{pH}$ was adjusted to 7.0 , for lysozyme is almost inactive at $\mathrm{pH}$ 8.0. EDTA was replaced by 4amino salicylate as it not only chelates but also releases protein from DNA (14). Finally, Pronase and lysozyme were used together, as it was found that the former did not interfere with lysis by lysozyme. 


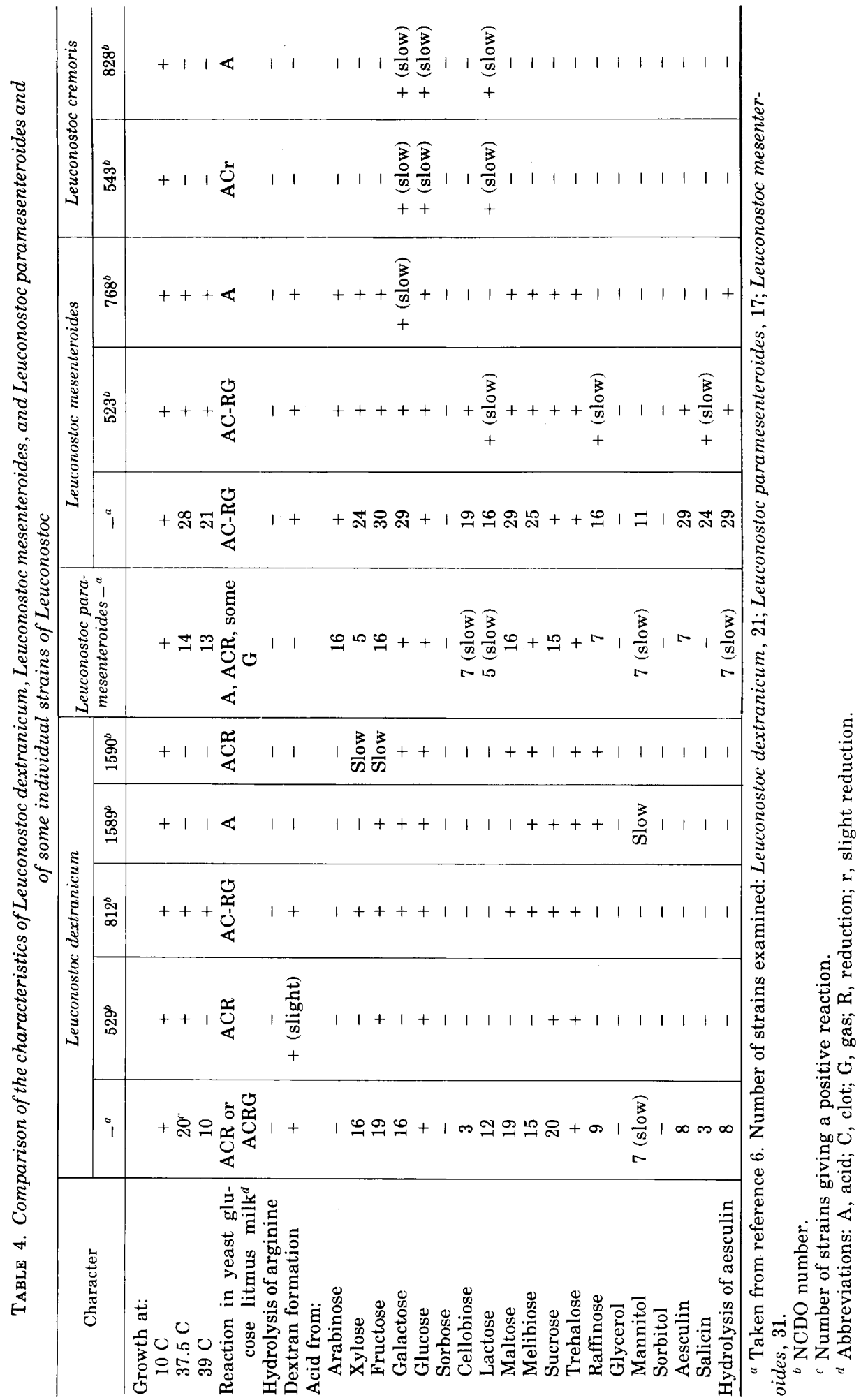


Some of the strains used were slow growing and gave low cell yields, and other strains, although growing well, gave a low yield of DNA. Therefore, it was advisable to select a method of hybridization which did not require large amounts of DNA. Competitive DNA hybridization techniques are favored by several workers, but these techniques require large amounts of DNA if the action of the homologous DNA is to be effectively swamped. De Ley and Tutgat (4) found that $700 \mu \mathrm{g}$ of DNA was necessary to counteract the effect of $2 \mu \mathrm{g}$ of labeled homologous DNA. In addition, competitive techniques exclude the direct comparison of two DNA preparations in the same solution. Therefore, a non-competitive filter method was adopted.

Phenotypically, four of the five non-acidophilic species of Leuconostoc form an apparently homologous group in which it is difficult to find clear divisions. The fifth species, Leuconostoc cremoris, is characterized by its ability to grow and form acid on a limited range of carbohydrates. However, estimates of the melting temperatures $\left(T_{m}\right)$ of the DNAs of the Leuconostoc species (10) showed that the $T_{m}$ of the DNA of Leuconostoc lactis was 1 to 2 degrees higher than those of the other species, including Leuconostoc oenos, the acidophilic species which has many distinguishing features. The hybridization studies have shown four genetic groups: Leuconostoc lactis and Leuconostoc oenos form two of these groups; a third comprises the three species Leuconostoc mesenteroides, Leuconostoc dextranicum, and Leuconostoc cremoris, whereas the fourth group contains Leuconostoc paramesenteroides. However, there are anomalies within these groups: NCDO 768, which phenotypically has no distinguishing features from other strains of Leuconostoc mesenteroides, appears to be genetically different because only $48 \%$ hybridization occurred between the DNA of NCDO 768 and that of the reference strain NCDO 523. The significance of this genetic variation cannot be assessed on the limited information available. The properties of both strains of Leuconostoc mesenteroides are shown in Table 4. There are no characteristics of NCDO 768 which would identify it as belonging to a separate species, and DNA/DNA hybridization cannot be used as the sole criterion for species differentiation. The high relationship between Leuconostoc cremoris and Leuconostoc mesenteroides is also difficult to interpret. The characters of NCDO 543 and NCDO 828 are also shown in Table 4. Both strains can be clearly separated from Leuconostoc mesenteroides. Leuconostoc cremoris and Streptococcus cremoris are the main bacteria of dairy starters, and no wild source of either is known. It may be that Leuconostoc cremoris has evolved from Leuconostoc mesenteroides or from Leuconostoc dextranicum in the special environment of the creamery. The results suggest that both Leuconostoc dextranicum and Leuconostoc cremoris may be subspecies of Leuconostoc mesenteroides rather than separate species. Only further results will clarify the taxonomic position of these bacteria.

The properties of NCDO 1589 and NCDO 1590 given in Table 4 suggest that these strains should belong to the same species. The DNA hybridization studies show that NCDO 1589 clearly belongs to the "mesenteroides/dextranicum" group. On the other hand, NCDO 1590 DNA gave only $48 \%$ hybridization with the DNA of Leuconostoc mesenteroides. From these results, it is concluded that NCDO 1589 and NCDO 1590 are genetically different despite their phenotypic similarities.

Other difficulties in the classification of the leuconostocs arise because, until recently, Leuconostoc paramesenteroides was regarded as a non-dextran-forming variant of Leuconostoc mesenteroides, but these organisms are now seen to be distinct genospecies. However, Pederson and Albury (21) found that dextran production from sucrose was an unstable character. If strains of either species gained or lost the ability to form dextran, the change might affect their genetic type only slightly, but phenotypic studies could place such strains in the wrong species. Genetic studies on a much larger number of strains are necessary to sort out and resolve these problems.

The results of this study have shown that the strains of Lactobacillus confusus and Lactobacillus viridescens examined are not closely related to the leuconostocs and, furthermore, that they are closer to each other than to any of the other strains examined. Although Lactobacillus confusus and Lactobacillus viridescens show a distant relationship to the non-acidophilic leuconostocs, an even more distant relationship is shown to the other species of heterofermentative lactobacilli. Similarly, the relationship between the acidophilic and non-acidophilic leuconostocs is more distant than that between the latter and Lactobacillus confusus or Lactobacillus viridescens.

The presently used generic dividing lines, which are based on morphology, cannot be justified by the results obtained here. It has already been suggested that all of the heterofermentative lactic acid bacteria should be in a single genus $(9,23)$, and this still appears to be 
an attractive arrangement. The alternative is to divide these bacteria into several genera, some of which would then only contain a single species. This is not appealing at present, for the relationships between the different species of the heterofermentative lactobacilli are not known.

\section{ACKNOWLEDGMENTS}

I wish to thank D. J. Knowles for valuable technical assistance and V. Zezula for helping to prepare DNA. Much help and advice in handling and counting the labeled DNA was received from $\mathrm{S}$. $\mathrm{H}$. Phillips.

\section{REPRINT REQUESTS}

Address reprint requests to: Dr. Ellen I. Garvie, National Institute for Research in Dairying, Shinfield, Reading RG2 9AT, England.

\section{LITERATURE CITED}

1. Abd-el-Malek, Y., and T. Gibson. 1948. Studies on the bacteriology of milk. 1. The streptococci of milk. J. Dairy Res. 15:233-248.

2. Burton, K. 1968. Determination of DNA concentration with diphenylamine. Methods Enzymol. 12B:163-165.

3. Chesterton, C. J., B. E. H. Coupar, and P. H. W. Butterworth. 1973. Large scale preparation of DNA for vast DNA excess hybridization. Anal. Biochem. 53:28-34.

4. De Ley, J., and R. Tutgat. 1970. Evaluation of membrane filter methods for DNA-DNA hybridization. Antonie van Leeuwenhoek J. Microbiol. Serol. 36:461-474.

5. Denhardt, D. T. 1966. A membrane filter technique for the detection of complimentary DNA. Biochem. Biophys. Res. Commun. 23:641-646.

6. Garvie, E. I. 1960. The genus Leuconostoc and its nomenclature. J. Dairy Res. 27:283-292.

7. Garvie, E. I. 1967. Leuconostoc oenos sp. nov. J. Gen. Microbiol. 48:431-438

8. Garvie, E. I. 1969. Lactic dehydrogenases of strains of the genus Leuconostoc. J. Gen. Microbiol, 58:85-94.

9. Garvie, E. I. 1975. Some properties of gas-forming lactic acid bacteria and their significance in classification, p. 339. In J. G. Carr, C. V. Cutting, and G. C. Whiting (ed.), Lactic acid bacteria in beverages and food. Academic Press Inc., London.
10. Garvie, E. I., V. Zezula, and V. Hill. 1974. Guanine plus cytosine content of the deoxyribonucleic acid of the leuconostocs and some heterofermentative lactobacilli. Int. J. Syst. Bacteriol. 24:248-251.

11. Hammer, B. W. 1920 . Volatile acid production of $S$. lacticus and the organisms associated with it in start. ers. Res. Bull. Iowa Agric. Exp. Sta. 63:59-96.

12. Hucker, G. J., and C. S. Pederson. 1930. Studies on the Coccaceae. XVI. The genus Leuconostoc. Bull. N.Y. State Agric. Exp. Sta. 167:1-80.

13. Hucker, G. J., and C. S. Pederson. 1957. Genus Leuconostoc, p. 531. In R. S. Breed, E. G. D. Murray, and N. R. Smith (ed.), Bergey's manual of determinative bacteriology, 7th ed. Balliere Tindall and Cox Ltd., London.

14. Kirby, K. S. 1957. A new method for the isolation of deoxyribonucleic acids and protein. Biochem. J. 66:495-504.

15. Kirby, K. S., E. Fox-Carter, and M. Guest. 1967. Isolation of deoxyribonucleic acid and ribosomal nucleic acid from bacteria. Biochem. J. 104:258-262.

16. Kourilsky, P., J. Leidner, and G. Y. Tremblay. 1971. DNA-DNA hybridization on filters at low temperatures in the presence of formamide or urea. Biochimie 53:1111-1114.

17. Lowry, O. H., N. J. Rosebrough, A. L. Farr, and R. J. Randall. 1951. Protein measurement with the Folin phenol reagent. J. Biol. Chem. 193:265-275.

18. deMan, J. C., M. Rogosa, and M. E. Sharpe. 1960. A medium for the cultivation of lactobacilli. J. Appl. Bacteriol. 23:130-135.

19. Marmur, J. 1961. A procedure for the isolation of deoxyribonucleic acid from micro-organisms. J. Mol. Biol. 3:208-218.

20. Metcalf, R. H., and R. H. Deibel. 1969. Differential lytic response of enterococci associated with addition order of lysozyme and anions. J. Bacteriol. 99:674680.

21. Pederson, C. S., and M. N. Albury. 1955. Variations among the heterofermentative lactic-acid bacteria. J. Bacteriol. 70:702-708.

22. Schneider, W. C. 1957. Determination of nucleic acids in tissue by pentose analysis. Methods Enzymol. 3:680-684

23. Sharpe, M. E., E. I. Garvie, and R. H. Tilbury. 1971. Some slime-forming heterofermentative species of the genus Lactobacillus. Appl. Microbiol. 23:389-399.

24. Young, F. E., and J. Spizizen. 1961. Physiological and genetic factors affecting transformation in Bacillus subtilis. J. Bacteriol. 81:823-829. 